\title{
LATINOS, ANGLOS, VOTERS, CANDIDATES, AND VOTING RIGHTS
}

\author{
JONATHAN NAGLER ${ }^{\dagger}$ \\ R. MICHAEL ALVAREZ ${ }^{\dagger+}$
}

In this paper we contrast the demographics, political preferences, and voting behavior of Latinos and Anglos. In doing so, we focus particularly on California because of the large quantity of economic, demographic, and political data concerning Latinos that are available for that state. Also, restricting ourselves to Latinos in California avoids the "problem" of cross-state diversity. We demonstrate that there is remarkable diversity among Latinos within California. Were we to add the Hispanic populations of other states to our analysis, particularly Cubans in Florida and Puerto Ricans in New York, we would magnify this diversity considerably. The purpose of our research is to provide suitable factual material for determining whether or not Latinos can constitute a "community of interest." We do not offer a new theory of "community of interest" here. But we think that a community of interest must be based more on shared preferences than on political outcomes (where "political outcomes" can be policy choices or candidates running for office).

\footnotetext{
${ }^{\dagger}$ Professor of Politics, New York University.

${ }^{+\dagger}$ Professor of Political Science, California Institute of Technology.

Prepared for the University of Pennsylvania Law Review's Symposium on The Law of Democracy. We thank Jonathan Steinberg and George Waters for their comments on earlier research. We also thank the participants of the University of Pennsylvania Law Review's Symposium for their comments. The authors can be reached at jonathan.nagler@nyu.edu and rma@hss.caltech.edu, respectively.

${ }^{1}$ The concept of preservation of "communities of interest" was one of three nonconstitutional redistricting principles presented by the plaintiffs in Carstens v. Lamm, 543 F. Supp. 68, 74, 82 (D. Colo. 1982) (mem.). The other two were compactness and contiguity, and preservation of county and municipal boundaries. Id. The court in Carstens defined communities of interest as "including ethnic, cultural, economic, trade area, geographic, and demographic factors." Id. at 83 n.38. In a recent manuscript, Winburn and Wagner note the vagueness of this definition: "While the courts have laid out guidelines for using communities of interest in the drawing of fair districts, the concept lacks a clear-cut definition." Jonathan Winburn \& Michael W. Wagner, Gerrymandering, Split Communities, and Forgotten Voters 6 (April 3, 2003), (Paper presented at the Annual Meeting of the Midwest Political Science Association, April 3-5, 2003), available at http://www.indiana.edu/ iupolsci/gradcv/ wagner/web_papers_gerrymander.pdf (last accessed October 23, 2004)
} 
In this paper we examine demographic diversity, diversity of opinion on issues (expressed both as votes on ballot propositions and responses to survey questions), and diversity in choices of candidates. We also examine the willingness of non-Latino voters to vote for Latino candidates. We show that California's Latino population is very diverse-ethnically, socially, and economically. We also demonstrate that this ethnic, social, and economic diversity has a political parallel: the Latino electorate is not monolithic, and the policies Latinos support are not necessarily policies that non-Latino groups unite to oppose. This leads to the conclusion that the concept of "community of interest" is problematic with regard to Latinos in California-a conclusion that has implications for the application of California's voting rights precedents, as recently seen in Cano v. Davis. ${ }^{2}$

\section{DEMOGRAPHIC AND ETHNIC DIVERSITY IN CALIFORNIA}

While voting rights disputes in the United States are often associated with the South, where the world was literally looked at as "Black and White," California cannot be thought of in terms of "Black and White," "Latino and White," or "White and non-White." In fact, California cannot even be thought of in terms of "Anglo, Hispanic, Asian, and Black" because there is too much diversity within each of these groups. For example, the term "Hispanic" can refer to people of completely different national origins, from different continents, and of different generations (e.g., both first-generation immigrants and second and later generations of Americans may be referred to as "Hispanic"). Similarly, in California the term "Asian" can refer to people of Chinese, Japanese, Vietnamese, or Cambodian origins, among others, with widely varying socioeconomic status. Thus, while

\footnotetext{
2211 F. Supp. 2d 1208 (C.D. Cal 2002); see infra Part VII.

${ }^{3}$ There is a vast literature on voting rights in the context of black-white relations, a literature much too large to effectively summarize here. See generally DAVID T. CANON, RACE, REDISTRICTING, AND REPRESENTATION: THE UNINTENDED CONSEQUENCES OF BLACK MAJORITY DISTRICTS (1999) (summarizing the research literature on political representation and voting rights); BERNARD GROFMAN ET AL., MINORITY REPRESENTATION AND THE QUEST FOR VOTING EQUALITY (1992) (discussing different legal and social science explanations for changing rates of minority representation in government); J. MORGAN KOUSSER, COLORBLIND INJUSTICE: MinORITY VOTING RIGHTS AND THE UNDOING OF THE SECOND RECONSTRUCTION (1999) (examining the history of minority voting rights, with a primary focus on those of Blacks); DAVID LUBLIN, THE PARADOX OF REPRESENTATION: RACIAL GERRYMANDERING MINORITY INTERESTS IN CONGRESS (1997) (empirically examining the correlation between racial redistricting and the race and ideology of elected representatives, focusing on Blacks and Latinos).
} 
we argue that it is a conceptual mistake to think of Californians primarily in racial and ethnic terms, we understand that such analyses are frequently offered in voting rights cases. Despite what is asserted in voting rights cases, the evidence does not support such a simpleminded approach to a state in which current political life is animated by a complex web of coalition building among diverse groups, and in which alliances are based on interests that regularly transcend race and ethnicity. ${ }^{4}$

The diversity of the non-White population of California greatly complicates any analysis of racial and ethnic politics in the state. Given the diversity of California, which we document in this Article, the assumption that political competition, representation, or policy making results from a conflict between Whites and non-Whites is incorrect. It is similarly incorrect to view politics in California as the result of a Latino versus non-Latino conflict, an Asian versus non-Asian conflict, or a Black versus non-Black conflict.

An analysis of data from the 2000 Census shows that California is a multiethnic state. ${ }^{5}$ In Table 1 we document, with data from the U.S. Census Bureau, the change in the racial composition of California's non-Hispanic population from 1990 to 2000. In 2000, Whites numbered $15,816,790$, or $69 \%$ of California's total non-Hispanic population of 22,905,092; however, the White non-Hispanic population in California fell by 7\% between 1990 and 2000. The increase in California's non-Hispanic population was produced by increases in the Black non-Hispanic population (increasing 4\% to 2,181,926 persons), and by increases in the Asian non-Hispanic population (increasing $38 \%$ to $3,752,596)$. California's non-Hispanic population is becoming more Asian.

\footnotetext{
${ }^{4}$ Coalitions spanning ethnic and racial divisions have been studied; however, the exact extent to which they occur, and the conditions under which they are possible, are clearly understudied social and political phenomena. For examples of cross-racial or cross-ethnic coalitions in California, see RAPHAEL J. SONENSHEIN, POLITICS IN BLACK AND WHITE: RACE AND POWER IN LOS ANGELES (1993) (analyzing "crossover" politics and race relations in Los Angeles); Leland Saito, Asian Americans and Latinos in San Gabriel Valley, California: Ethnic Political Cooperation and Redistricting, 1990-92, 19 AMERASIA J. 55 (1993) (discussing political cooperation between Asian-Americans and Latinos in the San Gabriel Valley).

${ }^{5}$ Cf. A Portrait of Race And Ethnicity in California: An Assessment of SOCIAL AND ECONOMIC WELl-BEING (Belinda I. Reyes ed., 2001) [hereinafter PORTRAIT OF RACE] (presenting a broad analysis of California's demographics, geographic diversity, socioeconomic differences, and political trends that largely parallels the analysis in this Article).

${ }^{6}$ The figures given above for Blacks, Whites and Asians represent the numbers of
} 
Table 1: Non-Hispanic Race and Ethnicity in California and Los Angeles County, 1990-2000

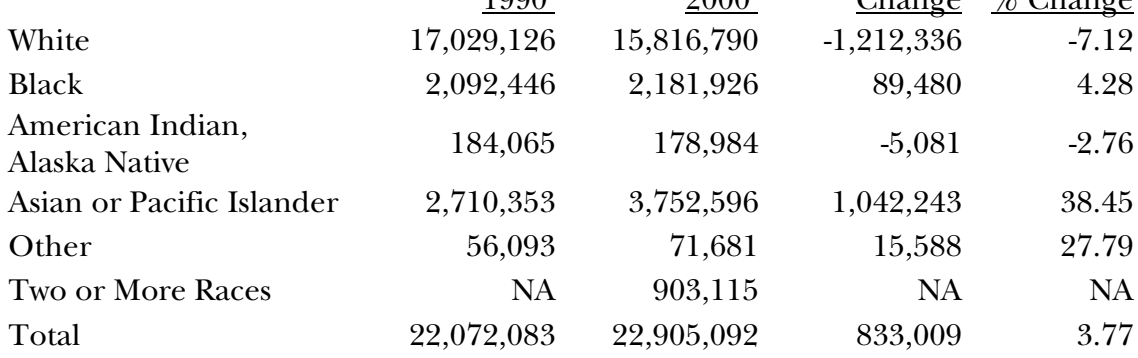

Table 2 provides a detailed look at the national origin composition of the Hispanic population in California. Using the detailed information on Hispanic origin available from the 2000 Census, we give the number of residents in most major Hispanic national origin groups. Beginning with our profile of the California Hispanic population, we see that Mexicans constitute a large share $(77 \%)$ of the total Hispanic population in California. Other national origin categories that have significant shares of the Hispanic population statewide are "other" Hispanics (14.2\%), Salvadorans (2.5\%), Guatemalans (1.3\%), and Puerto Ricans (1.3\%). Thus, before proceeding further, we note that the ethnic heterogeneity of Hispanics is substantial, especially for the population of a single state.

\footnotetext{
Census respondents who identified themselves as members of only one race.

${ }^{7}$ U.S. Census Bureau, Census 1990 Summary File 1 (SF1) (100-Percent Data), at tbl.P010, available at http://factfinder.census.gov (Hispanic Origin by Race) (last accessed Oct. 1, 2004) .

${ }^{8}$ U.S. Census Bureau, Census 2000 Summary File 1 (SF1) (100-Percent Data), at tbl.P4, available at http://factfinder.census.gov (Hispanic or Latino, and Not Hispanic or Latino, by Race) (last accessed Oct. 1, 2004).
} 
Table 2: Detailed Hispanic Origin, $2000^{9}$

\begin{tabular}{lrr} 
& California & $\underline{\text { CA\% }}$ \\
\cline { 2 - 3 } Mexican & $8,455,926$ & 77.11 \\
Puerto Rican & 140,570 & 1.28 \\
Cuban & 72,286 & 0.66 \\
Dominican & 5,047 & 0.05 \\
Guatemalan & 143,500 & 1.31 \\
Honduran & 30,372 & 0.28 \\
Nicaraguan & 51,336 & 0.47 \\
Panamanian & 10,688 & 0.10 \\
Salvadoran & 272,999 & 2.49 \\
Other Central American & 67,435 & 0.61 \\
Colombian & 33,275 & 0.30 \\
Ecuadorian & 18,115 & 0.17 \\
Peruvian & 44,200 & 0.40 \\
Other South American & 66,232 & 0.60 \\
Other Hispanic & $1,554,575$ & 14.18 \\
Total & $10,966,556$ &
\end{tabular}

We now turn to interracial marriage and persons claiming multracial identities. The 2000 U.S. Census questionnaires allowed respondents to indicate more than one identification with more than one race. $^{10}$ In California in 2000, the total number of persons of more than one race was $1,607,646,{ }^{11}$ and the figure for Los Angeles County was 469,781. ${ }^{12}$ As we documented in Table 1, in California 903,115 non-Hispanic persons indicated identification with more than one racial group, and 222,661 Los Angeles County non-Hispanic residents did the same.

Interracial relationships as documented by the U.S. Census Bureau are no longer rare in the United States. March 2000 Census data

\footnotetext{
${ }^{9}$ U.S. Census Bureau, Census 2000 Summary File 1 (SF1) (100-Percent Data), at tbl.PCT11, available at http://factfinder.census.gov (Hispanic or Latino, and Not Hispanic or Latino, by Race) (last accessed Oct. 1, 2004).

${ }^{10}$ The U.S. Census Bureau's 2000 U.S. Census Questionnaire, Form D-61A, can be accessed at http://www.census.gov/dmd/www/pdf/d61a.pdf. Question 6 instructs: "Mark one or more races to indicate what this person considers himself/herself to be."

${ }^{11}$ U.S. Census Bureau, 2000 Census of POPUlation And Housing: Profiles of GENERAL DEMOgRAPHic CHARACTERISTICS, CALIFORNIA 1 (2001), available at http://www.census.gov/prod/cen2000/dp1/2kh06.pdf (last accessed Oct. 1, 2004).

${ }^{12} I d$. at 20.
} 
indicate that the number of interracial marriages nationwide has increased to just over three million. ${ }^{13}$ Of the estimated three million interracial marriages reported in $2000,50.8 \%$ of them involved marriages between someone who was White and someone who was Hispanic. ${ }^{14}$ The Census Bureau reports that 1.7 million interracial households reported having children of their own under the age of eighteen. $^{15}$ A recent study by the Public Policy Institute of California shows that the multiracial/multiethnic birth rate had increased to over $14 \%$ of all births statewide in $1997 .{ }^{16}$ This is greater than the proportion of births where both parents were Asian (just under 10\%), and the proportion of births where both parents were Black (slightly more than 5\%). ${ }^{17}$ Last, the study found that the majority of all the multiracial/multiethnic births in 1997 were children with one Hispanic and one White parent (53\%), while almost $75 \%$ of all the multiracial/multiethnic births in 1997 involved couples with one White non-Hispanic parent and another parent that was Hispanic, Asian or Black. ${ }^{18}$ Thus, we have additional evidence that looking at the world in fixed categories of "Latino" and "non-Latino"—or "White," "Asian," "Latino," and "Black"-is inconsistent with reality.

Not only is there variation among Hispanics in ethnicity and national origin, but there is also variation on another demographic characteristic related to politics: income. Income is an important predictor of political preferences. And many political policy decisions have differential impacts on persons of different income levels. Table 3 presents data regarding the income distributions across the racial and ethnic groups in California: Whites, Hispanics, Asians, and Blacks. ${ }^{19}$ While the mean income of Hispanic families is considerably

${ }^{13}$ U.S. CENSUS BUREAU, MARCH 2000 CPS, at tbl.FG3, available at http://factfinder.census.gov (Hispanic or Latino, and Not Hispanic or Latino, by Race) (last accessed Oct. 1, 2004) (Married Couple Family Groups, by Presence of Own Children Under 18, and Age, Earnings, Education, and Race and Hispanic Origin of Both Spouses).

${ }^{14} \mathrm{Id}$.

${ }_{15} I d$.

${ }^{16}$ Sonya M. Tafoya, Check One or More... Mixed Race and Ethnicity in California, CAlifornia Counts: Population Trends \& Profiles, Jan. 2000, at 4 fig.1, available at http://www.ppic.org/content/pubs/CC_100STCC.pdf. Tafoya uses data from the California Vital Statistics Birth Records, which include information on the racial and ethnic backgrounds of fathers and mothers of children born in California.

${ }^{17} I d$. at 6 fig. 4 .

${ }^{18} I d$. at 6 fig. 5 .

${ }^{19}$ This table is from Cal. DeP'T of Fin., California Current Population SURVEY REPORT: MARCH 2000 DATA (2001). 
below the mean income of White families (over one-third of White families had incomes over $\$ 75,000$; only $14 \%$ of Hispanic families had incomes over $\$ 75,000)$, there is diversity of income within the set of Hispanic families. As we indicate later, we believe that Hispanic families with incomes over $\$ 50,000$ are likely to have more in common politically with Anglo families earning more than $\$ 50,000$ than they do with Hispanic families earning less than $\$ 15,000$.

\section{Table 3: Race, Ethnicity and Income in California $\mathbf{2 0 0 0}^{20}$}

\begin{tabular}{|c|c|c|c|c|c|}
\hline \multirow[b]{2}{*}{ Income Level } & \multicolumn{4}{|c|}{ Percent of Families } & \multirow[b]{2}{*}{$\begin{array}{c}\text { Number of } \\
\text { Families }\end{array}$} \\
\hline & $\underline{\text { White }}$ & $\underline{\text { Hispanic }}$ & $\begin{array}{l}\text { Asian/Pac. } \\
\text { Islander }\end{array}$ & $\underline{\text { Black }}$ & \\
\hline$\$ 0-4999$ & 1.30 & 3.10 & 2.37 & 5.44 & 179,000 \\
\hline$\$ 5000-9999$ & 2.21 & 4.56 & 2.58 & 7.06 & 263,000 \\
\hline$\$ 10,000-14,999$ & 3.47 & 8.04 & 6.19 & 8.87 & 443,000 \\
\hline$\$ 15,000-19,999$ & 4.66 & 11.44 & 2.78 & 7.26 & 533,000 \\
\hline$\$ 20,000-24,999$ & 5.21 & 10.58 & 3.71 & 4.64 & 533,000 \\
\hline$\$ 25,000-29,999$ & 5.27 & 9.33 & 3.71 & 12.10 & 544,000 \\
\hline$\$ 30,000-34,999$ & 4.89 & 8.09 & 3.81 & 2.62 & 452,000 \\
\hline$\$ 35,000-39,999$ & 3.79 & 6.02 & 4.02 & 5.44 & 372,000 \\
\hline$\$ 40,000-49,999$ & 9.66 & 8.90 & 9.28 & 8.06 & 760,000 \\
\hline$\$ 50,000-74,999$ & 22.81 & 16.34 & 18.25 & 16.73 & $1,639,000$ \\
\hline$\$ 75,000-99,999$ & 12.76 & 8.17 & 15.67 & 8.87 & 945,000 \\
\hline$\$ 100,000+$ & 23.95 & 5.46 & 27.53 & 12.70 & $1,506,000$ \\
\hline $\begin{array}{l}\text { Total Number } \\
\text { of Families }\end{array}$ & $4,380,000$ & $2,325,000$ & 970,000 & 496,000 & $8,171,000$ \\
\hline Mean Income & $\$ 74,300$ & $\$ 42,300$ & $\$ 78,200$ & $\$ 47,700$ & \\
\hline Median Income & $\$ 60,200$ & $\$ 31,200$ & $\$ 63,500$ & $\$ 36,500$ & \\
\hline
\end{tabular}

\section{LAtinOs Have Diverse POLITICAL VIEWS}

In the previous section we showed that the population of California is racially and ethnically diverse. In this section we examine political diversity of the Latino community. It is convenient for observers of California politics to discuss Latino voters as if they constitute a monolithic voting bloc in California. But this view is inaccurate. Latinos are not a monolithic voting bloc, as has been widely recognized in the po-

\footnotetext{
${ }^{20} I d$. at 32 tbl.46 (2001) (author's analysis). A family is a group of two or more persons residing together and related by birth, marriage, or adoption.
} 
litical science literature for some time. ${ }^{21}$ As we will show in this section, survey data collected from California Latinos provide additional strong support for our argument that Latinos are a diverse group. There is also substantial heterogeneity within the national Latino electorate regarding political preferences. ${ }^{22}$ In other words, Latino voters do not agree about many of the important issues of the day; and, in light of such disagreement, it makes little sense to talk about Latino voters as an overwhelming bloc in contemporary elections. The academic literature on Hispanic political preferences and voting behavior at the national level also concludes that Hispanics are a diverse, rather than a monolithic community; and that diversity extends across national origin groups, immigration status, cultural roots, socioeconomic status, and political preferences and opinions. ${ }^{23}$

We start by examining the level of Latino cohesion in California. Complicating the analysis of cohesion, though, is the lack of a precise definition of the concept of cohesion. To illustrate our use of the term cohesion, assume there are two groups, $A$ and $B$, and one issue under debate on which people either agree or disagree. In this hypothetical example, group $A$ would be totally cohesive if all members of group A either agreed or disagreed on the issue; thus, were a poll conducted about the issue, or if the issue were voted on by members of both groups, $100 \%$ of the members of group $A$ would have to have the same opinion in order to be considered totally cohesive. The converse, a total lack of cohesion, is the situation where exactly $50 \%$ of members of group $A$ agree with the issue and exactly $50 \%$ of the members of group $A$ disagree with the issue. Of course, points between total cohesion and a total lack of cohesion represent varying

${ }^{21}$ For an effective summary of what is becoming a very robust research literature in political science, see Rodolfo O. de la Garza, Latino Politics, 7 AnN. Rev. POL. SCI. 91 (2004).

${ }^{22}$ See, e.g., Rodolfo O. DE la GarZa ET AL., Latino Voices: Mexican, Puerto Rican, \& Cuban PERsPectives on American Politics 79-111 (1992) (describing the diversity of political beliefs, especially along national origin dimensions, within the Hispanic electorate).

${ }^{23}$ See, e.g., Louis DeSiPio, Counting on the Latino Vote: Latinos AS A NeW ELECTORATE 28-57 (1996) (profiling the Hispanic electorate regarding partisanship, ideology, and issues); ZOLTAN HAJNAL \& MARK BALDASSARE, Finding COMMON GROUND: RACIAL AND ETHNIC ATtITUdES IN CALIFORNIA 19-48 (2001) (profiling California's Latino population regarding policy, partisanship, and ideology) available at http://www.ppic.org/content/pubs/R_301ZHR.pdf (last visited Oct. 23, 2004); Albert M. Camarrillo \& Frank Bonilla, Hispanics in a Multicultural Society: A New American Dilemma, in 1 America BeCOMing: Racial Trends AND Their CONSEQuences 103-34 (Neil J. Smelser et al. eds., 2001) (documenting the demographic, economic, and political diversity of Hispanic population in America). 
degrees of cohesion. What we will demonstrate throughout this section is that Latinos are more cohesive than Whites and Asians, but considerably less cohesive than Blacks.

An important information resource for data on the general political orientations of Californians is the Public Policy Institute of California (PPIC) and its ongoing Statewide Survey project. A recent report by Zoltan Hajnal and Mark Baldassare examines in detail ten recent Statewide Surveys (from April 1998 to May 2000). ${ }^{24}$ The authors studied an aggregated set of survey responses to identical questions asked in all ten surveys. The aggregated sample contained survey responses from 19,569 individuals, of whom 4444 were Latino, 1104 were Black, 1024 were Asian, and the remainder were White. ${ }^{25}$ The typical PPIC Statewide Survey interviews about 2000 California adult residents, and also seeks to sample roughly 400 Latinos, 100 Asians and 100 Blacks statewide. ${ }^{26}$

The conclusions of the Hajnal and Baldassare study are important and worth quoting: "California's racial and ethnic differences are complex, and in each of the arenas of politics and public policy that we study, we find racial and ethnic differences, and racial and ethnic similarities." $^{27}$ They continue by arguing that apparent differences along racial and ethnic lines are almost always really driven by socioeconomic, immigrant, or citizenship status, or by partisan differences among the racial and economic groups. ${ }^{28}$

We present in Table 4 some of the results from this PPIC study. In this table we give the breakdowns for each of the four racial and ethnic groups by political ideology, partisanship, trust in government, overall mood, and most important issue. ${ }^{29}$ Two things are striking

\footnotetext{
${ }^{24}$ HAJNAL \& BALDASSARE, supra note 23, at 5; see also MARK BALDASSARE, CAlifornia in the NeW MillenNium: The Changing SOCIAL AND POlitical LANDSCAPE 211-48 (2000) (discussing survey methodology).

${ }^{25}$ HAJNAL \& BALDASSARE, supra note 23, at 64, tbl.A.1.

${ }^{26}$ See id. at 65 (explaining the mechanics of a typical PPIC Statewide Survey).

${ }^{27} I d$. at viii.

${ }^{28}$ Id.

29 "Political Ideology" and "Partisanship" were gauged in the PPIC Statewide Surveys using standard questions. The numbers for "Trust in Government" come from responses to the question, " $[\mathrm{h}]$ ow much of the time do you think you can trust the government in Washington to do what is right?" Id. at 43 tbl.4.11. "Financial Status" was gauged retrospectively with the question, "[w] ould you say that you and your family are financially better off or worse off or just about the same as you were a year ago?," and prospectively with the question, "[1] ooking ahead, do you think that a year from now you and your family will be financially better off or worse off or just about the same as now?" Id. at 55 tbl.5.5. "Overall Mood" comes from answers to the question,
} 
about the distributions of political ideology reported in Table 4. One is that for each group there is clearly a wide range of ideological identifications; for example, $30 \%$ of Latinos say they are liberal, $31 \%$ say they are moderate, and $39 \%$ say they are conservative. The second is that the distributions are quite similar across racial and ethnic groups: there is a slight tendency for Latinos to be more conservative than the other groups, and a slight tendency for Blacks to be more liberal than the other groups. ${ }^{30}$ Thus, while there are some slight differences between Latinos and Blacks relative to the remaining groups, it is clear that ideological diversity is the general rule for Californians no matter what their racial and ethnic identities.

Regarding partisanship among California adults, we see that Blacks are overwhelmingly Democratic, while Latinos are more Democratic than Whites, and significantly less Democratic than Blacks. Whites are the most Republican group, outpacing Asians by 12.9 percentage points, and Latinos and Blacks by much more in terms of their Republican identification. Notice that in a state known for leaning heavily Democratic, Whites are more likely to be Republican than Democratic. It is important to realize, when looking at any analysis of the willingness of Whites to vote for Latino candidates, that Whites are less likely than other groups to vote for Democratic candidates, completely independent of the candidate's ethnicity. Whites simply tend not to vote Democratic as often as do other groups in California. $^{31}$

Last, when asked about specific issue concerns-the overall issues that are seen as most important to each group-a strong consensus emerges: almost identical percentages of Latinos, Whites, Asians, and Blacks see education and schools, and then crime and gangs, as the two issues at the top of the policy agenda in California during this period. This level of consensus about the issue agenda is remarkable, and it again demonstrates that the basic political concerns of Californians are generally quite similar, no matter to which racial or ethnic group they belong.

"[d]o you think things in California are generally going in the right direction or the wrong direction?" Id. at 56 tbl.5.7. "The Most Important Policy Issue Question" also utilizes a standard format. Id. at 21 tbl.3.1.

${ }^{30}$ Hajnal and Baldassare indicate that the tendency of Latinos to be slightly more conservative is true even after accounting for partisan differences and socioeconomic and demographic factors. Id. at 37-38.

${ }^{31} I d$. at 37-38 tbl.4.3. 
Table 4: Political Orientation by Race and Ethnicity

\begin{tabular}{rrrrr} 
& Whites & Latinos & Asians & Blacks \\
\hline Political Ideology $^{32}$ & & & & \\
Very liberal & 8 & 9 & 8 & 14 \\
Somewhat liberal & 20 & 21 & 26 & 26 \\
Middle-of-the-road & 36 & 31 & 32 & 30 \\
Somewhat conservative $_{\text {Very conservative }}$ & 26 & 28 & 27 & 18 \\
& 10 & 11 & 7 & 12 \\
Partisanship $^{33}$ & & & & \\
Democrat & 39 & 61 & 40 & 77 \\
Republican & 44 & 21 & 31 & 7 \\
Other & 17 & 18 & 29 & 15
\end{tabular}

$\underline{\text { Trust in Government }}^{34}$

$\begin{array}{rrrrr}\text { Just about always } & 3 & 10 & 4 & 4 \\ \text { Most of the time } & 23 & 31 & 30 & 24 \\ \text { Only sometimes } & 65 & 52 & 59 & 60 \\ \text { Never } & 9 & 6 & 5 & 11 \\ \text { Don't know } & 0 & 1 & 2 & 1\end{array}$

$\underline{\text { Overall Mood }}^{35}$

$\begin{array}{rrrrr}\text { Right direction } & 60 & 65 & 68 & 51 \\ \text { Wrong direction } & 32 & 28 & 21 & 40 \\ \text { Don't know } & 8 & 7 & 11 & 9\end{array}$

Most Important Policy Issue $^{36}$ Schools, education Crime, gangs Jobs, the economy Immigration Environment, pollution Poverty

$\begin{array}{rrrr}26 & 28 & 27 & 28 \\ 12 & 16 & 14 & 13 \\ 4 & 6 & 6 & 9 \\ 7 & 5 & 6 & 4 \\ 5 & 2 & 3 & 2 \\ 3 & 4 & 3 & 5\end{array}$

\footnotetext{
${ }^{32} I d$. at 38 tbl.4.5.

${ }^{33} I d$. at 36.

${ }^{34} I d$. at 43 tbl.4.11.

${ }^{35} \mathrm{Id}$. at 56 tbl.5.7.

${ }^{36} I d$. at 21 tbl.3.1.
} 
In Table 5 we use Los Angeles Times exit poll data regarding Los Angeles County voters to examine the issue priorities that the four racial and ethnic groups used when deciding for whom to vote in the November 2000 presidential election. Each cell entry gives the percentage of persons in a group who listed the given issue as one of the two most important issues in determining their vote for president. First, it is clear from Table 5 that Los Angeles County voters of all racial and ethnic groups place varying levels of importance on each issue when deciding for whom to vote for president. White Los Angeles County voters in the 2000 general election had a variety of concerns: $36 \%$ saw education as one of the two most important issues in their decision making, $35 \%$ said moral and ethical values were important, $24 \%$ said the economy, and 20\% said taxes. Black voters in Los Angeles County agreed with Whites that education was one of the two most important issues (54\% said it was one of the two most important issues in their presidential vote), while $40 \%$ said the economy was important, $34 \%$ said social security, and $20 \%$ said moral and ethical values. Latino Los Angeles County voters largely agreed in the same relative ranking of issues as Blacks: 52\% of Latino voters thought education was one of the two most important issues, $45 \%$ said the economy, $38 \%$ said social security, and $25 \%$ said moral and ethical values. Asian voters in Los Angeles County also saw education as one of the two most important issues, as $49 \%$ rated it as one of the two most important, with $46 \%$ saying the economy, $39 \%$ saying social security, and $24 \%$ indicating moral and ethical values as important in their presidential vote. 
Table 5: Issue Priorities in Determining Presidential Vote, by Race and Ethnicity-2000 General Election, Los Angeles County ${ }^{37}$

\begin{tabular}{|l|c|c|c|c|}
\cline { 2 - 5 } \multicolumn{1}{c|}{} & Whites & Blacks & Latinos & Asians \\
\hline Moral/Ethical Values & 35 & 20 & 25 & 24 \\
\hline Jobs and Economy & 24 & 40 & 45 & 46 \\
\hline Education & 36 & 54 & 52 & 49 \\
\hline Social Security & 17 & 34 & 38 & 39 \\
\hline Taxes & 20 & 9 & 12 & 9 \\
\hline Abortion & 17 & 6 & 9 & 0 \\
\hline
\end{tabular}

Thus, the results in Table 5 document that each of the four racial and ethnic groups in Los Angeles County in the November 2000 presidential election had a diversity of political opinions; at least four issues were seen as important by at least $20 \%$ of the voters of each racial and ethnic group. Second, while Latino voters demonstrate a diversity of opinion about which issues are important, Latino voters in Los Angeles County agreed with Whites, Blacks, and Asians that education was the most important issue. Thus, voters from all racial and ethnic groups agreed that education was the most important issue in their presidential vote.

Is Latino political behavior heterogeneous as well? The answer is yes. We continue this analysis by examining data from the Los Angeles Times. In its exit poll of the 2000 elections, the Los Angeles Times asked all voters whether or not they supported two ballot measures: Propositions 38 (school vouchers) and 39 (school bonds). ${ }^{38}$ We give the statewide vote for these two ballot measures by the voter's stated race or ethnicity in Table 6. Proposition 38, which did not pass, failed due to opposition by all racial and ethnic groups in California's electorate. Latino voters opposed the school vouchers proposal (77\%); but so did White voters $(70 \%)$, Black voters $(68 \%)$, and Asian voters $(66 \%)$.

\footnotetext{
${ }^{37}$ The data in Table 5 is a weighted sample of Los Angeles County voters from a Los Angeles Times exit poll taken on November 7, 2000. For the national and statewide results of the Los Angeles Times 2000 exit poll, and a description of its methodology, see L.A. Times, Los ANgeles Times Poll, STUdy \#449/Exit Poll [hereinafter L.A. Times EXIT POLL REPORT] available at http://www.latimes.com/extras/timespoll/stats/pdfs /449ss.pdf (last accessed October 12, 2004).

${ }^{38}$ L.A. TIMES EXIT POLL REPORT, supra note 37, at 6.
} 
While there was some support in the Latino community for school vouchers, as shown by the $23 \%$ of Latinos who stated they supported this measure, the unified opposition of voters from across all racial and ethnic groups was an important part of the explanation for why this ballot measure failed to pass.

Table 6: Proposition Voting, 2000 General Election, by Race and Ethnicity ${ }^{39}$

Proposition 38: School Vouchers (Numbers are percentages)

\begin{tabular}{|c|c|c|}
\cline { 2 - 3 } \multicolumn{1}{c|}{} & Yes & No \\
\hline White & 30 & 70 \\
\hline Black & 32 & 68 \\
\hline Latino & 23 & 77 \\
\hline Asian & 34 & 66 \\
\hline
\end{tabular}

Proposition 39: School Bonds (Numbers are percentages)

\begin{tabular}{|c|c|c|}
\cline { 2 - 3 } \multicolumn{1}{c|}{} & Yes & No \\
\hline White & 50 & 50 \\
\hline Black & 60 & 40 \\
\hline Latino & 60 & 40 \\
\hline Asian & 57 & 43 \\
\hline
\end{tabular}

Proposition 39, on school bonds, met with a much different dynamic. This measure passed, winning $53 \%$ of the vote in this exit poll sample. Importantly, White voters were evenly split on the passage of this ballot measure, as $50 \%$ of Whites voted for passage and $50 \%$ of Whites voted against passage. Also divided were the votes of Blacks, Latinos and Asians: roughly six out of ten voters from each group supported passage of Proposition 39, while about four out of ten opposed this measure. The support for Proposition 39 from Black, Latino, and Asian voters was again an important explanation for the passage of this measure, even though these communities were clearly

$$
{ }^{39} I d \text {. }
$$


divided about the merits of Proposition 39. There are two important points here. First, Latino opinion overall is not that different from Anglo opinion on the two issues. Second, within the Latino community there is a remarkable lack of cohesion on these issues.

We can further demonstrate diversity of Latino opinion by looking at the Knight-Ridder survey of Latinos conducted in early 2000. This survey interviewed 2,721 Latino likely voters from across the nation, from May 26 through June 15, 2000. ${ }^{40}$ In the Knight-Ridder poll, Latino voters were asked about their opinions on abortion: do they favor laws that would make it easier for a woman to get an abortion, no change, or favor laws that would make it more difficult to get an abortion? Thirty-three percent of Latino voters favored laws making abortions easier, $14 \%$ supported no changes, and $44 \%$ favored laws that would make it more difficult for a woman to get an abortion. These same voters were asked their top priority for the use of the then-large federal budget surplus: $9 \%$ favored a tax cut, $11 \%$ wanted to pay off the national debt, $46 \%$ wanted to increase spending on social programs, and $31 \%$ wanted to make Social Security financially sound.

Illegal immigration and affirmative action were among the other important issues discussed in the Knight-Ridder survey. Latino voters were asked whether the United States government was doing enough, the right amount, or too much to stop immigrants from illegally entering the country. Forty-four percent said not enough, 30\% said just the right amount, and $16 \%$ said too much. Regarding affirmative action, the question asked whether these programs designed to help women and minorities get better jobs and education should be reduced, continued, or expanded: $11 \%$ favored reduction, $39 \%$ favored continuation, and $46 \%$ favored expansion.

Education vouchers and health insurance were the last issues discussed in the Knight-Ridder survey. Regarding education vouchers, Latino voters were asked whether the government should spend money to assist families who want to send their children to private or religious schools, or if such government money should only be spent on children in public schools. Thirty-one percent favored government financial assistance for families to send their children to private and religious schools, while $59 \%$ supported spending government

${ }^{40}$ The raw data for the Knight-Ridder survey was made available to the authors, and the statistics cited herein come from our analysis. See Steven Thomma, Courting the Hispanic Vote, MiAmi HeRALD, July 23, 2000 (discussing the methodology and results of the Knight Ridder 2000 Latino Voter Survey and noting that both authors studied the data). 
money only on children in public schools. The health insurance question asked whether the federal government should or should not guarantee health insurance for every legal resident and citizen. Eighty-five percent of Latino voters favored guaranteed health insurance, and only $11 \%$ opposed government-guaranteed health insurance. To repeat our earlier point, examination of recent survey data from California Latinos shows a great deal of diversity in their political preferences rather than overwhelming cohesion.

We also examined whether or not Latinos were more likely than Anglos to say certain issues were important after controlling for respondents' gender, age, and level of education. Using the KnightRidder survey, we estimated a simple model to examine the probability that an individual would list each of eleven issues as one of the two most important issues. We controlled for the respondents' gender, age, and education, and estimated the impact of the respondents' ethnicity above and beyond those demographics characteristics on their probability of naming each issue. The results are reported in Table 7. We found that on most issues, a respondent's being Latino rather than Anglo did not influence her probability of naming an issue. The exceptions to this were the issue of bilingual education, where being Latino made a respondent much more likely (.15) to name the issue as important, and bread-and-butter issues such as "Jobs and the Economy," which Latinos were also more likely than Anglos to name as important (.07). However, note that once we controlled for the respondents' age and education, Latinos are not more likely than Anglos to list improving education as an important issue. 
Table 7: Multivariate Analysis: Race, Ethnicity, and Issue Preferences

Issue Priority

Improving Education

Jobs and the Economy

Reducing Crime

Electing Experienced Leaders

Abortion

Bilingual Education

Stopping Special Interests

Health Care

Environment

Cutting Taxes

Electing New Leaders

$$
\begin{aligned}
& \underline{\text { Latinos }} \\
& \hline-.04 * \\
& .07 * * \\
& .01 \\
& -.02 \\
& -.01 \\
& .15 * * \\
& -.07 * * \\
& .05 * * \\
& -.04 * * \\
& -.04 * \\
& -.00
\end{aligned}
$$

$\frac{\text { Asians }}{-.07 *}$
-.04
-.01
-.03
$-.05 * *$
-.05
$-.08 * *$
$.09 * *$
-.03
.00
-.02

Each table entry is the estimated impact of respondent's ethnicity on the probability of listing the entry listed on each row as one of the most important issues relative to the likelihood that Whites will list the issue as most important. Estimates come from a probit model controlling for respondent's age, education, and gender (impact computed with other variables set to their mean).

* indicates estimate significant at .10 level

** indicates estimate significant at .05 level

But our conclusions have been challenged by others. For example, Mark Baldassare, the Senior Fellow at the PPIC who conducts the periodic surveys of Californians that we used in our own research, wrote:

In all, the evidence suggests that Latinos are very similar to whites in their views about California policies. At this time, there is no reason to think that the increased participation by Latinos in the political process will result in significant shifts in citizens' policy preferences enacted through elections. Whites and Latinos hold the same views about the state policy issues that are considered important. They think alike with regard to how state funds should be spent. They generally agree on what needs to be done to improve the state's public school system.

At the same time, Baldassare notes important differences between Latinos and Whites in California:

The differences between Latinos and whites are more subtle. Latinos are more enthusiastic about some reform proposals, such as school vouchers and state takeover of local schools. Latinos view state spending across all budget categories as more important. These trends probably

${ }^{41}$ BALDASSARE, supra note 24, at 127. 
reflect a more positive attitude among Latinos, and more cynicism among whites, about what the government can do for them. ${ }^{42}$

Thus, while Baldassare focuses on the similarities between White and Latino political preferences, he does note that there are some significant distinctions.

Therefore, the assumption that Latinos differ significantly from members of other racial and ethnic groups in California is open to question. There is evidence that can be brought to bear to argue either side of this case. This disagreement in the research on Latino political preferences and behavior, though, does mean that considerable caution should be taken when arguing that Latinos have clearly and consistently different preferences and behaviors from other groups in California.

\section{LATINO DIVERSITY ON PARTY IDENTIFICATION}

Partisanship is another important political preference that demonstrates diversity in the Latino electorate. A common assumption is that Latino voters in California are uniformly Democratic in their identification; however, this assumption is false. ${ }^{43}$ The best demonstration of this important result is in Table 8 , where we use a variety of sources to examine partisanship. The table lists responses to a standard question asking voters with which party they identify. We show that in the 1990, 1992, 1994, and 1996 general elections, Latino voter partisanship varied between $62 \%$ and $68 \%$ Democratic, and $15 \%$ to $21 \%$ Republican. In the two exit polls from the 1998 primary election, we found that Latino Democratic identification might have edged up slightly, to between $68 \%$ and $75 \%$.

42 Id.

${ }^{43}$ See R. Michael Alvarez \& Lisa Garcia Bedolla, The Foundations of Latino Voter Partisanship: Evidence from the 2000 Election, 65 J. POL. 31-49 (making a similar argument to the one presented here). 
Table 8: Race, Ethnicity and Partisanship, 1990-1998

\begin{tabular}{|c|c|c|c|c|c|}
\hline \multirow{2}{*}{ Ethnic Identification } & \multicolumn{4}{|c|}{ Partisan Identification } & \multirow[b]{2}{*}{ Total } \\
\hline & Democrat & Republican & Independent & Other & \\
\hline \multicolumn{5}{|c|}{1990 General Election, VRS $^{45}$} & \\
\hline White & 39 & 39 & 18 & 4 & 76 \\
\hline Black & 81 & 8 & 7 & 4 & 15 \\
\hline Hispanic-Latino & 64 & 20 & 13 & 3 & 5 \\
\hline Asian & 45 & 31 & 22 & 2 & 3 \\
\hline Other & 50 & 16 & 18 & 16 & 1 \\
\hline \multicolumn{5}{|c|}{1992 General Election, VRS ${ }^{46}$} & \\
\hline White & 40 & 36 & 19 & 6 & 72 \\
\hline Black & 83 & 5 & 9 & 2 & 11 \\
\hline Hispanic-Latino & 68 & 15 & 12 & 5 & 12 \\
\hline Asian & 40 & 33 & 18 & 10 & 3 \\
\hline Other & 53 & 18 & 18 & 13 & 2 \\
\hline \multicolumn{5}{|c|}{1994 General Election, $\mathrm{VNS}^{47}$} & \\
\hline White & 36 & 44 & 15 & 5 & 76 \\
\hline Black & 80 & 9 & 8 & 4 & 9 \\
\hline Hispanic-Latino & 66 & 17 & 13 & 4 & 10 \\
\hline Asian & 44 & 37 & 17 & 2 & 4 \\
\hline Other & 48 & 20 & 24 & 8 & 2 \\
\hline \multicolumn{5}{|c|}{1996 General Election, $\mathrm{VNS}^{48}$} & \\
\hline White & 40 & 38 & 16 & 6 & 70 \\
\hline Black & 73 & 11 & 9 & 6 & 10 \\
\hline Hispanic-Latino & 62 & 21 & 11 & 6 & 14 \\
\hline Asian & 35 & 46 & 14 & 6 & 4 \\
\hline Other & 48 & 23 & 16 & 13 & 2 \\
\hline \multicolumn{5}{|c|}{1998 Primary Election, ANPRG $^{49}$} & \\
\hline White & 38 & 30 & 29 & 3 & 62 \\
\hline Black & 82 & 7 & 5 & 6 & 5 \\
\hline Hispanic-Latino & 70 & 13 & 14 & 3 & 23 \\
\hline Asian & 45 & 23 & 30 & 2 & 8 \\
\hline Other & 46 & 19 & 24 & 10 & 2 \\
\hline \multicolumn{5}{|c|}{1998 Primary Election, LAT $^{50}$} & \\
\hline White & 45 & 5 & 44 & 6 & 76 \\
\hline Black & 80 & 8 & 5 & 6 & 7 \\
\hline Latino & 74 & 5 & 16 & 4 & 10 \\
\hline Asian & 40 & 8 & 42 & 10 & 4 \\
\hline Other & 53 & 14 & 23 & 10 & 3 \\
\hline
\end{tabular}

${ }^{44}$ Cell entries are row percentages, giving the percentage of respondents saying they identify with each party. The entries in the "Total" column give the percentage of the total sample represented by each ethnic group.

${ }^{45}$ Voter Research \& Surveys/CBS News/N.Y. Times, Voter Research and Surveys/CBS News/New York Times General Election Exit Poll: National File, 1990, [hereinafter VRS 1990] at http://webapp.icpsr.umich.edu/cocoon/ICPSR-STUDY/09602.xml (last accessed Oct. 1, 2004).

${ }^{46}$ Voter Research \& Surveys, Voter Research and Surveys General Election Polls, 1992, at http://webapp.icpsr.umich.edu/cocoon/ICPSR-STUDY/06102.xml (last accessed Oct. 1, 2004). 
These numbers imply that Latino voter partisanship in California does clearly lean towards the Democratic Party-but there is still a substantial segment of the Latino electorate that either is affiliated with the Republican Party or is not affiliated with either of the two major parties. Thus, in terms of partisanship, Latinos in California are not a monolithic voting bloc.

An important comparison in Table 8 is with the partisanship of Blacks in California. Notice that Black Democratic partisanship is almost always $80 \%$ or greater, and that Black partisanship is significantly more Democratic than Latino partisanship. This is significant because Blacks in California, and in the nation as a whole, are considered to be a solidly Democratic constituency. But compared to Blacks, it is clear that Latinos are not as strong in their affiliation with the Democratic Party in California, and thus are considered to be a target of opportunity for Republican recruitment efforts in a way that Blacks are not. ${ }^{51}$

Does the heterogeneity of the Latino electorate appear in their political behavior? The answer is "yes." We continue this analysis by examining data from the Los Angeles Times. In its exit poll conducted during the 2000 elections, the Los Angeles Times asked all voters which candidate they supported in the presidential and federal senatorial elections, as well as whether or not they supported two ballot measures-Propositions 38 (School Vouchers) and 39 (School Bonds). We provide the statewide votes in these two candidate races, by the voter's stated race or ethnicity, in Table 9.

${ }^{47}$ Voter News Serv., Voter News Service General Election Polls, 1994, at http://webapp.icpsr.umich.edu/cocoon/ICPSR-STUDY/06520.xml (last accessed Oct. 1, 2004).

${ }^{48}$ Voter News Serv., Voter News Service General Election Exit Polls, 1996, available at http://webapp.icpsr.umich.edu/cocoon/ICPSR-STUDY/06989.xml (last accessed Oct. 1, 2004).

${ }^{49}$ ANPRG: Alvarez \& Nagler, Political Research Group. The data for the section was collected by the authors. The study is described in R. Michael Alvarez \& Jonathan Nagler, Should I Stay or Should I Go? Sincere and Strategic Crossover Voting in California Assembly Races, in Voting AT THE POLITICAL FAUlt Line: CALIFORNIA'S EXPERIMENT WITH THE Blanket PRIMARY (Bruce E. Cain \& Elisabeth R. Gerber eds., 2002) [hereinafter Alvarez \& Nagler, Should I Stay or Should I Go?].

${ }^{50}$ L.A. Times, Los Angeles Times Poll, Study \#413/Exit Poll (June 2, 1998), available at http://www.usc.edu/dept/education/CMMR/227/Times227exitpoll.pdf (last accessed Oct. 23, 2004).

${ }^{51}$ See Juliet Eilperin, Battle Emerges over Latino Votes, WASH. POST, July 10, 2002, at A6 (describing efforts by the Republican Party to attract Latino voters in states such as California). 
In Table 9 we see Latinos voting for both the Democratic candidates for President and U.S. Senate, with $75 \%$ supporting Gore and $74 \%$ supporting Feinstein. Again, while this is a solid showing for these two Democratic candidates amongst Latino voters, we see that there is support amongst Latinos for the Republican candidates in both of these races-23\% of Latinos voted for Bush in the presidential race and $19 \%$ for Campbell in the senatorial race. Secondly, the Los Angeles Times exit poll data show that Blacks voted cohesively for the Democratic candidates in both races, with $85 \%$ of Blacks supporting Gore and $86 \%$ of Blacks supporting Feinstein. Only $63 \%$ of Asians supported Gore and only $64 \%$ supported Feinstein. Overall, this produces a portrait of Latino voting behavior in the 2000 general election's top-of-the-ticket races where Latino voters supported Democratic candidates, but not as strongly as the very cohesive Black vote in California.

Table 9: 2000 Presidential and Senate Voting by Race and Ethnicity

\begin{tabular}{cccc} 
& \multicolumn{2}{c}{ Presidential Election } \\
& $\underline{\text { Gore }}$ & $\underline{\text { Bush }}$ & Nader \\
White & 47 & 49 & 4 \\
Black & 85 & 14 & 1 \\
Latino & 75 & 23 & 2 \\
Asian & 63 & 33 & 4
\end{tabular}

\begin{tabular}{ccc} 
& $\begin{array}{c}\text { Senatorial Election } \\
\text { Feinstein }\end{array}$ & \\
\cline { 2 - 3 } White & 50 & 42 \\
Black & 86 & 9 \\
Latino & 74 & 19 \\
Asian & 64 & 33
\end{tabular}

The William C. Velasquez Institute (WCVI) conducted an exit poll of Latino voters in California in November 2000. WCVI interviewed 756 Latino voters in twenty-nine precincts statewide, using a two-stage

\footnotetext{
${ }^{52}$ L.A. TIMES EXIT POLL REPORT, supra note 37, at 1, 5-6.
} 
stratified probability-based sampling technique. ${ }^{53}$ By looking at the Latino demographics from WCVI data, we can see that the demographic distribution of voting within the Latino electorate looks very similar to the demographic distribution of voting within the Anglo electorate. $^{54}$ The WCVI exit poll found that $24 \%$ of California's Latino voters supported Bush, $2 \%$ supported another presidential candidate, and $74 \%$ supported Gore. We provide more detail of the 2000 presidential vote according to the WCVI exit poll in Table 10. In Table 10 we first see that there is a significant gender gap in the Latino presidential vote in California; $58 \%$ of Gore's Latino voters were Latinas, while $52 \%$ of Bush's were Latino males. There is also a tendency for Latino voters at the higher ends of the income spectrum to vote for Bush: $31 \%$ of Bush's votes came from those making $\$ 70,000$ or more, while $19 \%$ of Gore's votes came from Latino voters in that income range. Clearly, there are demographic differences in the profiles of Latinos who supported Gore and those who supported Bush. And an important thing to note is that these differences mirror the differences in the population at large, where it is well known that women favored Gore over Bush, ${ }^{55}$ and that those with higher incomes were more likely to vote Republican. ${ }^{56}$ Thus, ghettoizing Latinos as a distinct group of voters denies what they have in common with other members of the electorate.

\footnotetext{
${ }^{53}$ Details on the survey methodology are in Methodology: WCVI 2000 Exit Poll $\mathcal{E}$ Turnout Study, WCVI.ORG, Winter 2000, at 8, available at http://www.wcvi.org/files/ pdf/00_ca_newsletter.pdf.

${ }^{54}$ See CA Latino Vote in the 2000 Presidential Election: Profile by Candidate, WCVI.ORG, Winter 2000, at 4, (giving the demographic breakdown of Latino voters who responded to the survey by, for example, gender, age, household, education), available at http://www.wcvi.org/files/pdf/00_ca_newsletter.pdf (last accessed Oct. 1, 2004).

5 Paul R. Abramson et al., Change And Continuity in the 2000 And 2002 ELECTIONS 100-01 (2003) (reporting that there was a record gender gap of 12 percentage points between Gore and Bush in 2000).

${ }^{56}$ Id. at 103-04 (reporting that exit poll analysis of the 2000 presidential election revealed that more affluent voters were more likely to support Republicans).
} 
Table 10: 2000 California Latino Electorate: Demographics and Presidential Vote ${ }^{57}$

\begin{tabular}{|lll|}
\multicolumn{1}{c}{} & \multicolumn{2}{c}{ Presidential Vote } \\
\hline GENDER & \multicolumn{2}{c|}{ BUSH } \\
Male & 41.7 & 52 \\
Female & 58.3 & 48 \\
\hline AGE & & \\
$18-24$ & 15.9 & 14.3 \\
$25-29$ & 17 & 8.9 \\
$30-34$ & 11.7 & 17.9 \\
$35-39$ & 11.6 & 10.7 \\
$40-45$ & 10 & 13.7 \\
$46-49$ & 7.6 & 16.1 \\
$50-54$ & 11.7 & 6.5 \\
$55-59$ & 6.6 & 1.2 \\
$60-64$ & 3 & 6 \\
$65+$ & 4.7 & 4.8 \\
\hline INCOME & & \\
$<$ \$10,000 & 4.1 & 4.8 \\
\$10K-\$20K & 9.7 & 11.9 \\
\$20K-\$30K & 13 & 8.3 \\
\$30K-\$40K & 16.3 & 11.9 \\
\$40K-\$50K & 14.8 & 14.3 \\
\$50K-\$60K & 17.7 & 8.3 \\
\$60K-\$70K & 5.4 & 9.5 \\
\$70K-\$100K & 12 & 19 \\
$>\$ 100 \mathrm{~K}$ & 7 & 11.9 \\
\hline EDUCATION & & \\
Some HS or less & 10.2 & 11.7 \\
HS Graduate & 21.2 & 27.8 \\
Some College & 40 & 38.9 \\
College Graduate & 11.2 & 15.4 \\
Post-Graduate & 17.4 & 6.2 \\
\hline
\end{tabular}

${ }^{57}$ All figures are percentages of the respondents who voted for the particular candidate, for example the number 41.7 in the box that corresponds to "GORE" and "Male" means that $41.7 \%$ of respondents who voted for Albert Gore were male, not that $41.7 \%$ of male respondents voted for Gore. The data comes from the WCVI 2000 California Latino Voter Survey. See generally WCVI.ORG, supra note 54 (describing the Velasquez Institute survey and reporting the results). 


\section{LATINO ELECTORAL DIVERSITY}

In Table 11 we tabulate, according to various exit polls, the rate at which Latino voters supported Democratic gubernatorial candidates across the last decade. Focusing first on the general election estimates, we see that Latino support for Democratic gubernatorial candidates in 1990, 1994, and 1998 was consistently estimated by the various exit polls to be $70 \%$ or $71 \%$. The $1998 \mathrm{CNN}$ exit poll did, however, produce a higher Latino vote $(78 \%)$ for the Democratic candidate. In the 2002 election, though, the Latino Democratic gubernatorial vote fell considerably, to $65 \%$. If we take this voting data into consideration, we again note that there is a substantial segment of the Latino electorate, roughly three out of every ten Latino voters in California, who are not voting for Democratic gubernatorial candidates in general elections. This last piece of evidence also flies in the face of any argument or assumption that Latino voters constitute a strong voting bloc in California.

Table 11: Latino Vote Share and Democratic Support, 1990-2002California Gubernatorial Elections

\begin{tabular}{|c|c|c|c|}
\hline Election and Poll & $\begin{array}{c}\text { Latino } \\
\text { Vote Share }\end{array}$ & $\begin{array}{c}\text { Latino } \\
\text { Dem-Vote }\end{array}$ & $\begin{array}{c}\text { Anglo } \\
\text { Dem-Vote }\end{array}$ \\
\hline 1990 General, VRS $^{58}$ & 5 & 71 & 51 \\
\hline 1994 General, LAT ${ }^{59}$ & 9 & 70 & 36 \\
\hline 1994 General, CNN $^{60}$ & 9 & 71 & 33 \\
\hline 1998 Primary, LAT $^{61}$ & 12 & 83 & 57 \\
\hline 1998 Primary, $\mathrm{CNN}^{61}$ & 12 & 83 & 57 \\
\hline 1998 General, LAT $^{63}$ & 13 & 71 & 51 \\
\hline 1998 General, $\mathrm{CNN}^{64}$ & 14 & 78 & 50 \\
\hline 2002 Primary, $\mathrm{LAT}^{65}$ & 10 & - & - \\
\hline 2002 General, LAT $^{66}$ & 10 & 65 & 43 \\
\hline
\end{tabular}

${ }^{58}$ VRS 1990, supra note 45.

${ }^{59}$ L.A. Times, Demographic Profile of the Electorate: Los Angeles Times Poll, California General Election (Nov. 8, 1994), [hereinafter L.A. Times Exit POLL, 1994 GENERAL ELECTION]. available at http://www.latimes.com/media/acrobat/ 2002-11/5594568.pdf (last accessed Oct. 23, 2004)

${ }^{60} 1994$ California Exit Poll Results: Governor, CNN.COM, at http://www.cnn.com/ ELECTION/1998/states/CA/polls/CA94GH.html (last accessed Oct. 23, 2004). 


\section{CALIFORnia Voters: SUPPORT For LATINO CANDidATES}

Obviously, the ability of Latino candidates to win elections depends on the willingness of people to vote for them, and that willingness on the part of White, Asian, and Black voters is what we now consider. To be clear on terminology, we use the term crossover voting below to indicate a voter of one ethnic group voting for a candidate of another ethnic group rather than choosing a candidate from her own ethnic group. Thus, a White voter choosing a Latino candidate in a race between a Latino candidate and a White candidate would be an example of crossing over. While we also want to know the extent to which Asians and Blacks vote for Latinos, we would not call an Asian or Black voter choosing a Latino candidate in a Latino-White race a "crossover voter."

There are two different methodologies social scientists utilize to study voting behavior in general, and crossover voting in particular. ${ }^{67}$ The preferred methodology for studying voting behavior and cross-

${ }^{61}$ Demographic Profile of the Electorate (June 4, 1998), L.A. TIMES (displaying exit poll results), at http://www.latimes.com/media/acrobat/2001-10/789032.pdf (last accessed October 1, 2004).

${ }^{62}$ Keating Holland, Exit Poll: Union Voters Contributed to Davis' Victory, CNN.COM, June 3, 1998 at http://www.cnn.com/ALLPOLITICS/1998/06/03/exit.poll/ (last accessed October 1, 2004).

${ }^{63}$ Portrait of the Electorate, L.A. Times (displaying the results of an exit poll taken at the general election) [hereinafter L.A. Times Exit Poll, 1998 General Election] available at http://www.latimes.com/media/acrobat/2001-09/732038.pdf (last accessed October 23, 2004).

${ }^{64}$ Exit Poll, CNN.COM, at http://www.cnn.com/ELECTION/1998/states/CA/G/ exit.poll.html (last accessed October 23, 2004).

${ }^{65}$ How Propositions 40 and 45 Fared Among Voters, L.A. Times (displaying the results of the exit poll) available at http://www.latimes.com/media/acrobat/2002-03/ 2235583.pdf (last accessed October 23, 2004).

${ }^{66}$ Times Exit Poll Results, L.A. TIMES, available at http://www.latimes.com/ media/acrobat/2002-11/5344027.pdf (last accessed October 23, 2004).

${ }^{67}$ For more discussion of the social science methodologies regarding crossover voting analysis, see Alvarez \& Nagler, Should I Stay or Should I Go? supra note 49 (discussing the use of exit poll data to study crossover voting behavior); R. Michael Alvarez \& Jonathan Nagler, A New Approach for Modeling Strategic Voting in Multiparty Systems, 30 BRIT. J. POL. SCI. 804-15 (2000) [hereinafter Alvarez \& Nagler, A New Approach] (discussing use of survey data to study strategic voting behavior); R. Michael Alvarez \& Jonathan Nagler, Analysis of Crossover and Strategic Voting, Expert Witness Report, California Democratic Party v. Jones (1997); see also W. K. Tam Cho \& B.J. Gaines, The Limits of Ecological Inference: The Case of Split-Ticket Voting, 48 AM. J. POL. SCI. 152-71 (2004) (discussing problems associated with using ecological data to study partisan split-ticket voting). 
over voting is for the researcher to use survey data. ${ }^{68}$ Survey data, accumulated through face-to-face interviews with real voters leaving the polling places on election day (exit polls) or through telephone interviews with likely voters just before or just after an election, is regarded as the most accurate type of information available about individual political behavior. ${ }^{69}$ After all, a survey involves interviews with individual voters themselves, so behavior, motivations, and personal demographic attributes can be measured for each individual voter in a survey study.

A less preferable social science methodology for studying voting behavior and crossover voting is for the researcher to use ecological data $^{70}$ - data that is generally collected at the precinct level-to make inferences from the aggregated precinct level data about the behavior of individuals. The problem with using ecological data to study voting behavior and crossover voting is that it requires strong assumptions. The problems with ecological analysis are well-known and welldocumented, and they arise because there is usually too little information about the individual to know with any degree of accuracy her true behavior. Achen and Shively summarized the problem:

We need to understand how individuals have been grouped into aggregates before we can interpret aggregate results. Statistically, the aggregation process introduces unknown parameters which can rarely be estimated and which are inextricably mixed with the parameters of interest. Untangling them requires assumptions whose validity can be supported only by reference to theory or data outside the problem at hand.

These problems become even more difficult when there are multiple groups to study within each unit. To try to infer the behavior of Latinos or Anglos from aggregate information regarding units that contain not only Latinos and Anglos, but also Asians, Blacks, and other ethnic groups, is even more difficult. ${ }^{72}$

\footnotetext{
${ }^{68}$ See generally Alvarez \& Nagler, A New Approach, supra note 67 (justifying the use of survey data for studying political behavior).

${ }^{69} I d$.

${ }^{70}$ Christopher H. ACHen \& W. Phillips Shively, Cross-Level Inference 30-32 (1995).

${ }^{71} I d$. at $10-11$.

${ }^{72}$ For further discussion of the problems associated with using ecological inference techniques to study minority political behavior in this context, see generally David A. Freedman et al., Ecological Regression and Voting Rights, 15 EVALUATION REV. 673 (1991) (critiquing the use of ecological regression for studying Latino and nonLatino voting patterns); Bernard Grofman, Statistics Without Substance: A Critique of
} 
Thus, whenever possible, social scientists primarily use survey data when studying voting behavior and crossover voting; only in situations where survey data is not available do they resort to the more problematic ecological analysis. This is the methodological approach we adopt, and it is the same approach that we have used in our past research on crossover voting. ${ }^{73}$

The Los Angeles Times exit poll, interviewing actual voters as they leave polling places right after casting their ballots, has been conducted in a series of elections involving Latino candidates. The Los Angeles Times has surveyed respondents about the following election match-ups involving Latino candidates for statewide office: Democrat Art Torres versus Republican Chuck Quackenbush (Insurance Commissioner, November 1994); Charles M. Calderon versus Bill Lockyer and Lynn Schenk (Democratic Nomination for Attorney General, March 1998); and Democrat Cruz Bustamante versus Republican Tim Leslie (Lieutenant Governor, November 1998). The Los Angeles Times has surveyed voters about the following election match-ups involving Latino candidates in City of Los Angeles races: Antonio Villaraigosa and Xavier Becerra versus other candidates (Mayor, March 2001); Rocky Delgadillo versus Mike Feuer, Lea Purwin D'Agostino and Frank Tavelman (City Attorney, March 2001); Villaraigosa versus Hahn (Mayoral Runoff, June 2001); Delgadillo versus Feuer (City Attorney Runoff, June 2001).

We summarize the White voter crossover in each of these races, for a variety of geographical levels, in Table $12 .^{74}$ This table lists the percentage of White voters in the exit poll sample who report voting

Freedman et al., and Clark and Morrison, 15 Evaluation REv. 746 (1991) (using ecological regression to study racially polarized voting); Allan J. Lichtman, Passing the Test: Ecological Regression Analysis in the Los Angeles County Voting Rights Cast and Beyond, 15 EVALUATION REV. 770 (1991) (analyzing ecological regression used in studying racially polarized voting); Daron R. Shaw, Estimating Racially Polarized Voting: A View From the States, 50 POL. RES. Q. 49 (1997) (comparing ecological and survey estimates of group voting patterns).

73 See Alvarez \& Nagler, Analysis of Crossover and Strategic Voting, supra note 67.

${ }^{74}$ The statewide Los Angeles Times exit polls include a variable allowing us to separate out voters in Los Angeles County. The Los Angeles Times exit polls for the Los Angeles City elections in 2001 include a variable that allows us to separate out only San Fernando Valley voters. For the 1998 samples we report crossover estimates for both statewide and Los Angeles County samples; for the 2001 samples we report crossover estimates for both Los Angeles City and San Fernando Valley samples. For further elaboration on the argument in this section, see Marisa A. Abrajano et al., Race-Based Versus Issue Voting: A Natural Experiment: The 2001 City of Los Angeles Elections (Mar. 29, 2003) (unpublished manuscript), available at http://www.nyu.edu/gsas/ $\mathrm{dept} /$ politics/faculty/nagler/lamayor25.pdf. 
for a Latino candidate in the election. ${ }^{75}$ The races listed in Table 12 are ordered by the extent of White voter crossover in the race and area. The highest level of White voter crossover occurred in Los Angeles County in the 1998 general election for Lieutenant Governor, where Bustamante received $55 \%$ of the votes cast by White voters. Bustamante also received high White crossover in the statewide sample, receiving $44 \%$ of White votes statewide as measured in the Los Angeles Times exit poll. The next two races, sorted by White crossover, involve Torres's run for Insurance Commissioner in 1994. We see that Torres received 41\% White crossover in Los Angeles County in the 1994 general election and $42 \%$ White crossover statewide.

Table 12: White Voting for Latino Candidates, 1994-2001

\begin{tabular}{|c|c|}
\hline$\underline{\text { Election and Area }}$ & \% White Crossover \\
\hline Nov. 1998 Lt. Governor, L.A. County ${ }^{76}$ & 55 \\
\hline Nov. 1998 Lt. Governor, statewide ${ }^{77}$ & 44 \\
\hline Nov. 1994 Insurance Commissioner, statewide ${ }^{78}$ & 42 \\
\hline Nov. 1994 Insurance Commissioner, L.A. County ${ }^{79}$ & 41 \\
\hline June 2001 L.A. Mayor, L.A. City ${ }^{80}$ & 41 \\
\hline June 2001 L.A. City Attorney, L.A. City ${ }^{81}$ & 39 \\
\hline June 2001 L.A. Mayor, San Fernando Valley ${ }^{82}$ & 38 \\
\hline June 2001 L.A. City Attorney, San Fernando Valley ${ }^{83}$ & 37 \\
\hline Apr. 2001 L.A. Mayor, San Fernando Valley ${ }^{84}$ & 27 \\
\hline Apr. 2001 L.A. Mayor, L.A. City ${ }^{85}$ & 26 \\
\hline Apr. 2001 L.A. City Attorney, L.A. City ${ }^{86}$ & 26 \\
\hline Apr. 2001 L.A. City Attorney, San Fernando Valley ${ }^{87}$ & 22 \\
\hline June 1998 Attorney General, L.A. County ${ }^{88}$ & 9 \\
\hline June 1998 Attorney General, statewide ${ }^{89}$ & 7 \\
\hline
\end{tabular}

${ }^{75}$ In the April 2001 Los Angeles Mayoral primary there were two Latino candidates running, Villaraigosa and Becerra; in Table 12 we present the percentage of White voters who reported voting for either Latino candidate.

${ }^{76}$ L.A. Times, Study \#420/Exit Poll: California General Election (Nov. 3, 1998), available at http://www.latimes.com/media/acrobat/2003-07/8628701.pdf (last accessed Oct. 1, 2004).

${ }^{77} \mathrm{Id}$.

${ }^{78}$ The source of this data is Los Angeles Times exit poll data (on file with authors).

${ }^{79}$ The source of this data is Los Angeles Times exit poll data (on file with authors).

${ }^{80}$ Voter Profile (June 7, 2001), L.A. TIMES, (displaying the results of an exit poll taken after the Los Angeles elections for mayor and city attorney) available at http://www.latimes.com/media/acrobat/2001-07/316963.pdf (last accessed Oct. 23, 
The 2001 elections in Los Angeles and the Los Angeles Times exit poll data give us another perspective on the general voting behavior of Whites and Latinos regarding support for Latino and non-Latino candidates. For each candidate in the two citywide races involving Latino candidates, we can look-instead of at crossover voting as we did in Table 12-at a more general measure of voters' propensities to support Latino or non-Latino candidates. This is done by examining the percentages of White, Asian, and Black voters who chose to vote for at least one of the Latino candidates on the ballot in the runoff elections in 2001, and comparing that to the percentages of Latino voters who were willing to vote for at least one non-Latino candidate in these same citywide elections. This analysis gives us a measure of the overall propensity of White, Asian, and Black voters to support Latino candidates, and of Latino voters to support non-Latino candidates.

We present this analysis in Table 13 . Notice that fully $67.8 \%$ of White voters chose to support at least one Latino candidate out of the two available (Delgadillo and Villaraigosa). This is true even though Delgadillo and Villaraigosa individually received only $39 \%$ and $41 \%$ of the White vote, respectively. What this makes clear is that the number of White voters choosing to support Latino candidates is larger than the share of the vote any one Latino candidate receives. The numbers of Blacks and Asians who chose to support at least one Latino candidate are similar: $67.1 \%$ for Blacks, and $62.6 \%$ for Asians. However, the interpretation of Black and Asian political behavior is very different. Fifty-nine percent of Blacks supported Delgadillo; thus, adding Black support for Villaraigosa does not change very much the per-

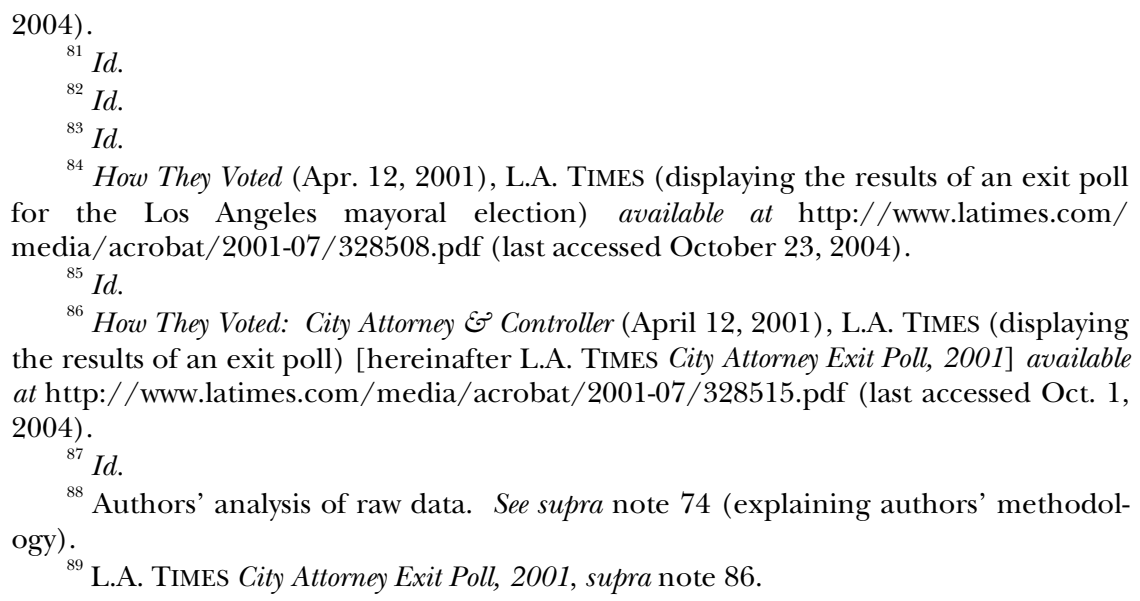


centage of Blacks who support Latino candidates. Asians' voting behavior appears more like that of Whites: the Asians voting for Villaraigosa and Delgadillo comprised $47 \%$ and 39\%, respectively; but the percentage of Asians voting for at least one of the two candidates was significantly higher: $62.6 \%$. Thus, solid majorities of White, Black, and Asian voters are willing to vote for a Latino candidate. Significantly, the question of how many choose to do so depends on the politics, campaigns, and characteristics of the candidate.

Table 13: Willingness of White, Black, and Asian Voters to Vote for at Least One Latino Candidate-June 2001 Los Angeles City Runoff Elections ${ }^{90}$

\begin{tabular}{|c|c|c|}
\cline { 2 - 3 } \multicolumn{1}{c|}{} & $\begin{array}{c}\text { At Least 1 } \\
\text { Latino Candidate }\end{array}$ & $\begin{array}{c}\text { At least 1 } \\
\text { Non-Latino Candidate }\end{array}$ \\
\hline Whites & $67.8 \%$ & $\mathrm{X}$ \\
Blacks & $67.1 \%$ & $\mathrm{X}$ \\
Asians & $62.6 \%$ & $\mathrm{X}$ \\
Latinos & $\mathrm{X}$ & $33.8 \%$ \\
\hline
\end{tabular}

Table 14 presents data from the same Los Angeles Times exit polls, but with more detail for the various racial and ethnic groups, as well as a breakdown of the votes for Villaraigosa and Becerra in the April 2001 Los Angeles mayoral election. The data presented in the cells in Table 14 provide the percentage of each racial or ethnic group in the exit poll sample who reported voting for a particular Latino candidate, in the given geographic area, for the particular election. The Latino candidate vote shares by racial and ethnic groups are sorted by the percentage of Whites supporting each Latino candidate; thus, the data are in the same order as in Table 12.

\footnotetext{
${ }^{90}$ The data in this table come from Los Angeles Times 2001 runoff exit polls, see supra notes $80-87$.
} 
Table 14: Voting for Latino Candidates, 1994-2001, by Race and Ethnicity

\begin{tabular}{|c|c|c|c|c|c|}
\hline Election and Area & Candidate & $\begin{array}{c}\text { \% White } \\
\text { support }\end{array}$ & $\begin{array}{c}\text { \% Black } \\
\text { support }\end{array}$ & $\begin{array}{c}\text { \% Asian } \\
\text { support }\end{array}$ & $\begin{array}{c}\text { \% Latino } \\
\text { support }\end{array}$ \\
\hline $\begin{array}{c}\text { Nov. 1998 Lt. Governor, } \\
\text { L.A. County }\end{array}$ & Bustamante & 55 & 91 & 47 & 86 \\
\hline $\begin{array}{c}\text { Nov. 1998 Lt. Governor, } \\
\text { statewide }\end{array}$ & Bustamante & 44 & 76 & 51 & 74 \\
\hline $\begin{array}{c}\text { Nov. 1994 Insurance } \\
\text { Comm'r, L.A. County }\end{array}$ & Torres & 42 & 90 & 44 & 75 \\
\hline $\begin{array}{c}\text { Nov. 1994 Insurance } \\
\text { Comm'r, statewide }\end{array}$ & Torres & 41 & 88 & 51 & 77 \\
\hline $\begin{array}{c}\text { June 2001 L.A. Mayor, } \\
\text { L.A. City }\end{array}$ & Villaraigosa & 41 & 20 & 35 & 82 \\
\hline $\begin{array}{c}\text { June 2001 L.A. City Att'y, } \\
\text { L.A. City }\end{array}$ & Delgadillo & 39 & 59 & 47 & 79 \\
\hline $\begin{array}{c}\text { June 2001 L.A. Mayor, } \\
\text { San Fernando Valley }\end{array}$ & Villaraigosa & 38 & 35 & 36 & 81 \\
\hline $\begin{array}{c}\text { June 2001 L.A. City Att'y, } \\
\text { San Fernando Valley }\end{array}$ & Delgadillo & 37 & 56 & 47 & 75 \\
\hline $\begin{array}{c}\text { April 2001 L.A. City Att'y, } \\
\text { L.A. City }\end{array}$ & Delgadillo & 26 & 43 & 28 & 64 \\
\hline $\begin{array}{c}\text { April 2001 L.A. Mayor, } \\
\text { San Fernando Valley }\end{array}$ & Villaraigosa & 24 & 24 & 19 & 61 \\
\hline $\begin{array}{c}\text { April 2001 L.A. Mayor, } \\
\text { L.A. City }\end{array}$ & Villaraigosa & 23 & 12 & 23 & 62 \\
\hline $\begin{array}{c}\text { April 2001 L.A. City Att'y, } \\
\text { San Fernando Valley }\end{array}$ & Delgadillo & 22 & 43 & 23 & 59 \\
\hline $\begin{array}{c}\text { June 1998 Atty-General, } \\
\text { L.A. County }\end{array}$ & Calderon & 9 & 13 & 14 & 43 \\
\hline $\begin{array}{c}\text { June 1998 Atty-Gen., } \\
\text { statewide }\end{array}$ & Calderon & 7 & 15 & 12 & 34 \\
\hline $\begin{array}{c}\text { April 2001 L.A. Mayor, } \\
\text { L.A. City }\end{array}$ & Becerra & 3 & 2 & 5 & 17 \\
\hline $\begin{array}{c}\text { April 2001 L.A. Mayor, } \\
\text { San Fernando Valley }\end{array}$ & Becerra & 3 & 4 & 6 & 12 \\
\hline
\end{tabular}

In the November 1998 race for Lieutenant Governor, not only did Bustamante receive strong White crossover support, he also received strong support from both Blacks and Asians. In the Los Angeles County sample, Bustamante received votes from $91 \%$ of Blacks and $47 \%$ of Asians; additionally, $86 \%$ of Latinos in the Los Angeles County sample supported Bustamante. Statewide, the basic pattern was the same: in the statewide exit poll sample, Bustamante received $44 \%$ of the White vote, $76 \%$ of the Black vote, and $51 \%$ of the Asian vote.

Also running in a statewide general election, but in 1994, was Art Torres when he sought to become the Insurance Commissioner. Tor- 
res picked up 42\% White crossover in Los Angeles County, as well as $90 \%$ of the votes of Los Angeles County Blacks, $44 \%$ of the Asian vote, and $75 \%$ of the Latino vote. Statewide, Torres's performance among the four racial and ethnic groups was similar to his Los Angeles County performance: he received $41 \%$ of the statewide White vote, $88 \%$ of the statewide Black vote, $51 \%$ of the Asian vote, and $77 \%$ of the Latino vote.

The next four rows in Table 14 list support for Villaraigosa or Delgadillo in the 2001 Los Angeles runoff elections, arranged by the percentage of White voters who supported the Latino candidate in each race. First, throughout the entire City of Los Angeles, Villaraigosa drew strong support from Latino voters $(82 \%$ of Latinos in the city supported his candidacy), and he also received substantial support from both White and Asian voters (41\% and 35\% respectively); Villaraigosa did not receive much support from Blacks in the City (20\%). Delgadillo, on the other hand, drew roughly the same share of votes from Latinos and Whites throughout the City of Los Angeles, picking up $79 \%$ of the Latino vote and $39 \%$ of the White vote. Delgadillo, though, fared better than Villaraigosa amongst Black and Asian voters, getting $59 \%$ of the Black vote and $47 \%$ of the Asian vote. When we examine these same two races, but restrict the sample to voters in the San Fernando Valley, we find a very similar pattern of candidate support among each racial and ethnic group, but with one exception. Villaraigosa picked up a much greater percentage of the vote from Blacks in the San Fernando Valley than citywide: Villaraigosa received a full $35 \%$ of the Black vote in the Valley, but only $20 \%$ citywide.

The next four entries, and the last two entries in Table 14 detail the April 2001 Los Angeles primary elections. The highest level of White crossover in the City of Los Angeles was for Delgadillo, who received $26 \%$ of the White crossover vote in a primary election involving three other White candidates. Delgadillo received $64 \%$ of Latino votes cast citywide, $43 \%$ of the citywide Black vote, and $28 \%$ of the citywide Asian vote. In the San Fernando Valley, Delgadillo received roughly the same degree of support across the racial and ethnic groups as he did citywide in the primary election: $59 \%$ of Latino votes, $43 \%$ of Black votes, $23 \%$ of Asian votes, and $22 \%$ of White votes. In the San Fernando Valley, Villaraigosa received $24 \%$ of the White vote, $61 \%$ of the Latino vote, $24 \%$ of the Black vote, and $19 \%$ of the Asian vote; citywide Villaraigosa received virtually the same degree of support from Latinos (62\%), Whites (23\%), and Asians (23\%), but Villaraigosa received fewer votes from Blacks citywide in the primary 
election (12\%), than he did in the San Fernando Valley (24\%). Villaraigosa's support among all the racial and ethnic groups must be viewed in the appropriate context: there were fifteen candidates running in the primary election, and there was also another prominent Latino candidate, Xavier Becerra.

The last race covered by the Los Angeles Times exit polls involving a Latino candidate was the June 1998 open primary, where Charles Calderon ran for the Democratic Party's nomination in the race for Attorney General. There were four other Democratic candidates in the primary (including the eventual nominee, Bill Lockyer), two Republicans, and four minor-party candidates. As shown in Table 14, among Los Angeles County voters, Calderon garnered 9\% of White votes, $13 \%$ of Black votes, $14 \%$ of Asian votes, and $43 \%$ of Latino votes. In the open primary voting statewide, Calderon received $34 \%$ of Latino votes, $15 \%$ of Black votes, $12 \%$ of Asian votes, and $7 \%$ of White votes. According to the Los Angeles Times exit poll, most Latino voters statewide supported a non-Latino candidate $(66 \%)$, with $24 \%$ voting for Lockyer, $11 \%$ supporting Lynn Schenk (another Democratic candidate), $21 \%$ voting for one of the two Republicans, and $10 \%$ voting for another candidate. Calderon had stronger support among Latinos in Los Angeles County than he did statewide, but still a majority of Los Angeles County Latinos voted for a non-Latino candidate (57\%).

This analysis of the basic crossover voting estimates from the Los Angeles Times exit polls documents three basic conclusions about racial and ethnic crossover voting. First, Latino candidates can and do receive substantial numbers of White, Black, and Asian votes-in the San Fernando Valley, the City of Los Angeles, Los Angeles County, and throughout the state. Second, the extent to which White voters support Latino candidates varies across candidates and races and is not a fixed measure depending simply upon ethnicity or race. Third, the data presented in Tables 12 and 14 document that both the nonWhite and the non-Latino voting coalitions are diverse and dynamic, shifting with the nature of the election, the geographic area, and the particular set of choices facing voters.

In fact, Table 14 documents that Latino candidates can win elections in California and the City of Los Angeles, and they do so when they build multiethnic coalitions. Bustamante's victory in 1998 and Delgadillo's win in 2001 both document the importance for Latino candidates of building coalitions that include significant support from all four racial and ethnic groups. Bustamante's 1998 statewide victory was built upon a coalition that had $44 \%$ of the White vote and a ma- 
jority of the Black, Asian and Latino vote. Delgadillo's victory in 2001 in the City of Los Angeles was similar: Delgadillo received 39\% of the White vote, majorities of the Black and Latino vote, and almost a majority of the Asian vote. The exception to this rule is Torres' 1994 campaign for Insurance Commissioner: despite picking up $41 \%$ of the statewide White vote and majority support from Blacks, Asians, and Latinos statewide, Torres lost this election to Quackenbush. While the racial coalitions both Torres and Bustamante built in these elections were quite similar in composition, the underlying composition of the California electorate had changed dramatically between 1994 and 1998: in 1994 the electorate was estimated to be 83\% White, $5 \%$ Black, 8\% Latino, and 4\% Asian; ${ }^{91}$ in 1998 the electorate was estimated to be $64 \%$ White, $13 \%$ Black, $13 \%$ Latino, and $8 \%$ Asian. $^{92}$ It is clear-considering the expansion of California's Black, Latino and Asian electorates-that a Latino candidate can win statewide elected office by constructing a coalition that reaches across all of California's racial and ethnic groups.

Table 15 presents more detailed information about the White crossover voters in the three statewide samples in which we have Latino candidates running for office (the November 1994 race for Insurance Commissioner, the June 1998 race for Attorney General, and the November 1998 race for Lieutenant Governor), and in the four Los Angeles City samples where, again, we have Latino candidates running for office (the two April 2001 races and the two June 2001 races for mayor and city attorney). We provide a profile of the White crossover vote in each race by breaking down crossover voters according to income, ${ }^{93}$ education, and ideology.

91 See L.A. Times Exit Poll, 1994 General Election, supra note 59.

${ }^{92}$ See L.A. Times Exit Poll, 1998 General Election, supra note 63.

${ }^{93}$ In Table 15, "low" income means less than $\$ 20,000$ in yearly family income, "moderate" means between $\$ 20,000$ and $\$ 75,000$, and "high" means over $\$ 75,000$. 
Table 15: Attributes of White Crossover Voters, 1994-2001 ${ }^{94}$

\begin{tabular}{|l|ccc|ccccccc|}
\multicolumn{1}{c}{} & \multicolumn{1}{c}{ Income } & \multicolumn{3}{c}{ Education } & \multicolumn{3}{c|}{ Ideology } \\
\cline { 2 - 9 } \multicolumn{1}{c|}{} & Low & Mod. & High & $\begin{array}{c}\text { High } \\
\text { Sch. }\end{array}$ & College & $\begin{array}{c}\text { Post- } \\
\text { Coll }\end{array}$ & $\begin{array}{c}\text { Mod- } \\
\text { Liberal } \\
\text { erate }\end{array}$ & Cons. \\
\hline $\begin{array}{l}\text { Nov. 1994 } \\
\text { Ins. Comm'r }\end{array}$ & 14.5 & 60.9 & 24.6 & 18.1 & 53.7 & 28.2 & 33.1 & 57.3 & 9.5 \\
$\begin{array}{l}\text { June 1998 } \\
\text { Att'y General }\end{array}$ & 11.1 & 55.6 & 33.3 & 21.1 & 56.7 & 22.3 & 28.8 & 60.2 & 10.9 \\
$\begin{array}{l}\text { Nov. 1998 } \\
\text { Lt. Gov }\end{array}$ & 22.8 & 38.1 & 39.2 & 13.4 & 53.6 & 33.1 & 39.5 & 51.1 & 9.3 \\
$\begin{array}{l}\text { Apr. 2001 } \\
\text { L.A. City Att'y }\end{array}$ & 6.3 & 40.1 & 53.6 & 10.5 & 58.3 & 31.2 & 35.2 & 31.7 & 33.1 \\
$\begin{array}{l}\text { Apr. 2001 } \\
\text { L.A. Mayor }\end{array}$ & 3.6 & 41.7 & 54.6 & 5.9 & 48.9 & 45.2 & 75.5 & 18.6 & 5.9 \\
$\begin{array}{l}\text { June 2001 } \\
\text { L.A. City Att'y }\end{array}$ & 3.9 & 46.7 & 49.4 & 13.4 & 51.1 & 35.5 & 39.4 & 24.1 & 23.4 \\
$\begin{array}{l}\text { June 2001 } \\
\text { L.A. Mayor }\end{array}$ & 5.8 & 43 & 51.2 & 11.8 & 56 & 32.2 & 34.6 & 32.9 & 32.5 \\
\hline
\end{tabular}

The portrait that emerges of White crossover voters in the three statewide races for which we have exit polling data indicates that moderate- to high-income White voters, with higher levels of educational attainment, who are moderates or liberals, are more willing to vote for Latino candidates. As the second-to-last row in Table 15 shows, this means that White crossover voters statewide are coming from the overwhelming majority of the White voter population: $92.6 \%$ of White voters in the state have either moderate or high levels of income, $84.6 \%$ of White voters in the state have a college education or better, and $63.6 \%$ of White voters are liberal or moderate in their political views.

When we turn to examine the profile of White crossover voters in the City of Los Angeles, we see a different picture. Generally, White crossover voters in Los Angeles, as compared to those statewide, tend to have slightly higher incomes, be better-educated, and be more ideologically diverse. White crossover voters reflect the later popula-

\footnotetext{
${ }^{94}$ Numbers are percentages. The data in this table come from the authors' analysis of the raw data from Los Angeles Times exit polls from 1994, 1998, 2000, and 2001, supra notes 76-89.
} 
tion of White voters in the City of Los Angeles, again demonstrating that a Latino candidate in the City of Los Angeles can be appealing to mainstream White voters. Thus, Latino candidates can gain significant numbers of White votes in the City of Los Angeles, just as they can statewide, by appealing to mainstream White voters.

\section{LATINO Voters AND THE 2003 RECALl ELECTION}

The 2003 gubernatorial recall election constitutes an interesting case for our analysis. First, it is the most recent statewide election in California, so data from it provides a very recent portrait of racial and ethnic political behavior in the state. Second, the recall election also included a racially divisive ballot measure, Proposition 54 (the "Racial Privacy Initiative"), that-like the prior Proposition 209-was targeted at eliminating affirmative action policies by governmental agencies in California. ${ }^{95}$ Third, the recall election involved a prominent Latino candidate, Cruz Bustamante (the sitting Lieutenant Governor); thus, we can examine the extent to which Latinos supported Bustamante (who, as a Latino, would be considered by many as a "candidate of choice") and the extent to which members of other racial and ethnic groups supported Bustamante's candidacy to be the first Latino governor of California in modern political history.

${ }^{95}$ The official title and summary of Proposition 54 as contained in the voter information guide for the 2003 recall election was as follows:

CLASSIFICATION BY RACE, ETHNICITY, COLOR, OR NATIONAL ORI-

GIN. INITIATIVE CONSTITUTIONAL AMENDMENT.

Amends Constitution to prohibit state and local governments from using race, ethnicity, color, or national origin to classify current or prospective students, contractors or employees in public education, contracting, or employment operations. Does not prohibit classification by sex.

Prohibition also covers persons subject to other operations of government unless Legislature finds compelling state interest, authorizes by two-thirds of each house, and Governor approves.

"Classifying" defined as separating, sorting, or organizing persons or personal data. Exemptions include: medical data; law enforcement descriptions; prisoner and undercover assignments; actions maintaining federal funding.

Cal. Sec'y of State, Official Voter Information Guide: Statewide SPecial ElECTION, TUESDAY, OCTOBER 7, 2003, at 40 (2003), available at http://vote2003.ss.ca.gov/voterguide/english.pdf (last accessed Oct. 23, 2004). For previous research on Proposition 209, see LYDIA CHAVEZ, THE COLOR BIND: CALIFORNiA's BATTLE TO END AFFiRmATIVE ACTION (1998) (discussing the California Civil Rights Initiative, which became known as Proposition 209); R. Michael Alvarez \& Lisa Garcia Bedolla, The Revolution Against Affirmative Action in California: Racism, Economics, and Proposition 209, STATE POL. \& POL'Y Q., Spring 2004, at 1-17 (discussing racially polarized voting on Proposition 209, which "banned the use of affirmative action in state hiring, contracting, and public university admissions"). 
We provide basic data on the recall election vote, by racial and ethnic groups, in Table 16. The table gives information on the political behavior of each of the four racial and ethnic groups regarding: their estimated share of the recall election votes, their preferences on the recall question, their voting behavior on the three major replacement candidates, and their preferences for Proposition 54.

Table 16: Race, Ethnicity and the Recall Election ${ }^{96}$

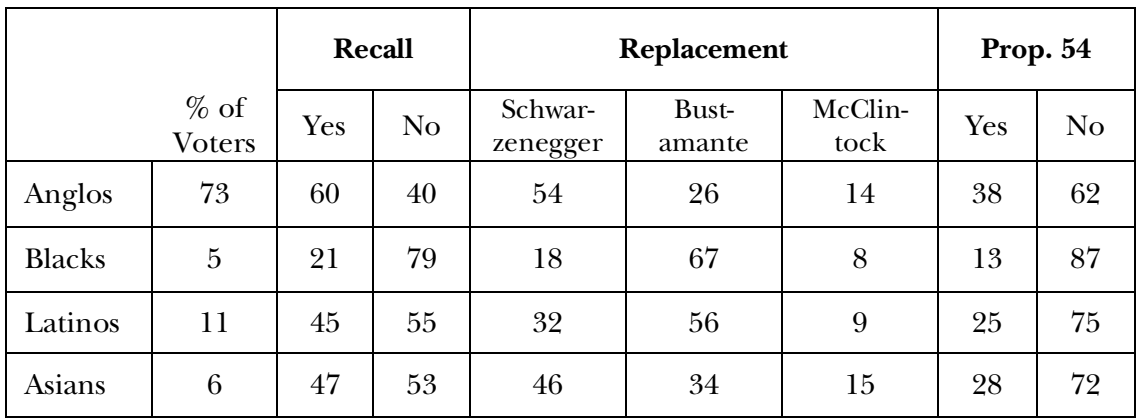

First, Table 16 documents that the recall election-and the candidacy of a Latino for governor-failed to boost Latino voter turnout. ${ }^{97}$ The exit poll estimates that the recall electorate was made up of $11 \%$ Latino voters, a figure that is roughly the same as Latino voter turnout in other recent statewide elections. Next, we note that Latino voters were divided on the recall question itself: $45 \%$ of Latino voters supported the recall election, while $55 \%$ opposed it. This is in contrast to White voters (who tended to support more strongly the recall election) and Black voters (who tended to oppose more strongly the recall election). Thus, the recall election failed to generate a groundswell of Latino voter turnout, and Latino voters were quite mixed in their behavior regarding the recall question.

Next, when it comes to the candidate replacement question, $56 \%$ of Latino voters cast ballots for Democratic Latino candidate Cruz Bustamante, 32\% of Latino voters supported Republican Arnold Schwarzenegger, and 9\% supported Republican Tom McClintock.

96 L.A. Times, Los Angeles Times Poll, Study \#490: EXit Poll, California RECALL ELECTION (Oct. 7, 2003), available at http://www.latimes.com/ media/acrobat/2003-11/10201233.pdf (last accessed Oct. 1, 2004).

${ }^{97}$ A similar argument is made by M.A. Barreto and R. Ramirez, Minority Participation and the California Recall: Latino, Black, and Asian Voting Trends, 1990-2003, PS: POL. SCI. \& POL, January 2004, at 11, 11-14. 
Thus, while a majority of Latino voters did support the Latino gubernatorial candidate in the race, a strong $44 \%$ of Latino voters did not support Bustamante, with $41 \%$ of Latino voters supporting one of two Anglo Republican candidates. In reference to previous statewide gubernatorial elections, this is the weakest support that Latino voters in California have given to a Democratic gubernatorial candidate, who in this case was a Latino.

Also worth noting is the number of votes for Bustamante by other racial and ethnic minority groups: $26 \%$ of Anglos, $67 \%$ of Blacks, and $34 \%$ of Asians supported Bustamante. Thus, the recall data again help document the willingness of Anglos, Blacks, and Asians to support Latino candidates in California.

Last, Table 16 provides data on the Proposition 54 vote (Proposition 54 was defeated in the election, with $63.9 \%$ of votes cast in opposition). Blacks strongly opposed Proposition 54, with $87 \%$ voting against the measure. Latinos and Asians also strongly opposed this ballot measure, with $75 \%$ of Latinos and $72 \%$ of Asians voting against it. Anglos also opposed the measure, though not as strongly as the other racial and ethnic groups, as $62 \%$ said they voted against this anti-affirmative action measure. These data document a convergence of opinion against Proposition 54 across racial and ethnic groups.

\section{CONCLUSIONS AND IMPLICATIONS}

Our analysis has considered social, economic, and political data on Latinos in California. We have provided a great deal of data that documents two important conclusions about racial and ethnic politics in California, conclusions that have some legal implications.

First, Latinos in California are not a monolithic group. We have shown that Latinos are ethnically, socially, and economically diverse. We have also shown that Latinos in the state are divided in their opinions about important political matters, and that they are by no means unified in their partisanship, their ideology, or their support for a wide variety of political candidates-including Latino candidates. This does not mean that a single issue could not arise on which Latinos and non-Latinos would have opposing views. But the overwhelming evidence that we have presented here shows that such issues would be the exception, not the norm.

We documented this diversity across partisan affiliations, opinions on important political issues, voting behavior on important ballot measures, and voting for gubernatorial candidates in recent elections in California. We also demonstrated that in recently conducted na- 
tional studies of Latinos, this same diversity is very apparent in the political preferences of Latinos. In fact, the academic research literature on Latino political preferences and voting behavior focuses on the diversity in the Latino electorate. All of this evidence casts considerable doubt on the assumption that Latinos are a unified voting bloc in California or the nation.

Second, we have also shown that, in California, Whites, Blacks, and Asians are not a unified anti-Latino voting bloc. In particular, we have provided considerable data that show that Whites have supported Latino candidates in California, at both the state and local levels. While our analysis is not exhaustive-we recognize that there are an enormous number of legislative, congressional, and local races involving Latino candidates that we simply lack the space to considerwe do believe that our analysis of White "crossover" voting shows that Whites cannot be considered a group that is uniformly or necessarily opposed to Latino candidates.

Third, while the more general subject of Latino political representation is well beyond the scope of this paper, recent trends document that Latino candidates are winning offices in greater numbers at all levels of California politics. The number of Hispanic elected officials in California increased from 460 in 1984 to 789 in $1998 .^{98}$ A more recent report shows that the number of Hispanic elected officials in California was 987 in 2003. ${ }^{99}$ This implies that by 1998 Hispanics held roughly $10 \%$ of the available elected offices in California, a percentage approximately equal to Hispanic vote shares in the late 1990s; furthermore, this fraction might have risen to over $12 \%$ by $2003 .{ }^{100}$ Also, by the late 1990s and the early years of the next decade, Latino candidates were having success at all levels of California government: one Latino was elected to statewide office, seven Latinos were in California's congressional delegation, and twenty-seven were in the state legislature. ${ }^{101}$ In recent years, three Latinos have served as Speaker of the State Assembly. ${ }^{102}$

${ }^{98}$ PORTRAIT OF RACE, supra note 5, at 181 fig.9.12.

99 NAT'L ASS'N OF LATINO ElEcted OfFicials, NATIONAL DiRECTORY OF LATINO ELECTED OFFICIALS 20 (2003).

${ }^{100}$ PORTRAIT OF RACE, supra note 5, at 170 fig.9.1, 181 fig.9.12. The $12 \%$ estimate in 2003 is obtained by assuming that the number of elected offices statewide in 2003 is the same as it was in 1998 when the editors estimated the fraction of Latino elected officials at $10 \%$; we simply divided 987 by 7890 , which yields an estimated fraction of Latino elected officials of all elected officials in California of $12.5 \%$.

${ }^{101}$ NAT'L ASS'N OF LATINO ELECTED OfFICIALS, supra note 99, at 20.

102 Cruz Bustamante was elected in 1996, Antonio Villaraigosa in 1998, and Fabian 
The social, economic, and political trends that we have documented in our research have immediate legal implications. In particular, the diversity of Latino social, economic, and political behavior implies that it is difficult to apply the concept of "communities of interest" to this group in California. It also suggests that Whites, Blacks, and Asians are not unified in their opposition to Latino interests, that members of these other racial and ethnic groups support Latino candidates, and that it is difficult to argue that non-Latinos are unified in their opposition to Latino interests.

This was the line of reasoning that led to the recent Cano $v$. Davis $^{103}$ redistricting decision in California. The Cano Court held that there were not grounds on which to overturn the redistricting plan that had been passed by the state legislature and signed by the governor into law because of the lack of cohesion amongst Latinos, the fact that non-Latinos are not necessarily opposed to Latino candidates and Latino interests, and the diversity of Latinos in the state. ${ }^{104}$ Given this decision, and the data we have offered here on the diversity of Latino behavior and interests in California, it is likely that future voting rights cases in the state may have difficulty meeting the criteria set forth in earlier cases, like Thornburg $v$. Gingles. ${ }^{105}$

Nunez in 2004.

103211 F. Supp. 2d 1208 (C.D. Cal 2002) (per curiam) (three-judge panel), aff'd mem., 537 U.S. 1100 (2003).

${ }^{104}$ Some observers have noted that the simple fact that this case arose shows the diversity of opinions amongst Latinos in California. For example, Kevin R. Johnson wrote:

Intra-Latina/o tensions erupted in Cano v. Davis, in which the Mexican American Legal Defense and Education Fund accused the California Legislature, with a record number of Latina/os, of diluting Latina/o voting power in violation of the Voting Rights Act in the state's congressional redistricting scheme. This visible conflict within the Mexican American community, which is generally more cohesive than the greater Latina/o community, suggests the possible splintering of Latina/os along political, national origin, and other lines. In the long term, for example, one could envision a voting rights claim by Central Americans, who comprise a significant percentage of the Latina/o population in Los Angeles County, contending that they are being locked out of the electoral process by politicians of Mexican ancestry, who comprise the vast majority of Latina/os in state and local elected offices in California. Similar occurrences might happen among different Latina/o national origin groups in New York and Florida, which have diverse Latina/o populations like California's.

Kevin R. Johnson, The Struggle for Civil Rights: The Need for, and Impediments to, Political Coalitions Among and Within Minority Groups, 63 LA. L. REV. 759, 781 (2003) (footnotes omitted).

105478 U.S. 30 (1986) (establishing minority group cohesion and racially polarized voting as two of three criteria necessary to prove discriminatory effect in redistricting cases). 